University of Wollongong

Research Online

Faculty of Engineering and Information

Faculty of Engineering and Information

Sciences - Papers: Part A

Sciences

$1-1-2016$

\title{
Waste activated sludge hydrolysis and acidification: a comparison between sodium hydroxide and steel slag addition
}

\author{
Ying Zhang \\ University of Wollongong, Tongji University, yz393@uowmail.edu.au \\ Chaojie Zhang \\ Tongji University \\ Xuan Zhang \\ East China Electric Power Design Institute Co. Ltd, zhangxuan2010@yahoo.com.cn \\ Leiyu Feng \\ Tongji University \\ Yongmei Li \\ Tongji University
}

See next page for additional authors

Follow this and additional works at: https://ro.uow.edu.au/eispapers

Part of the Engineering Commons, and the Science and Technology Studies Commons

Research Online is the open access institutional repository for the University of Wollongong. For further information contact the UOW Library: research-pubs@uow.edu.au 


\title{
Waste activated sludge hydrolysis and acidification: a comparison between sodium hydroxide and steel slag addition
}

\begin{abstract}
Alkaline treatment with steel slag and $\mathrm{NaOH}$ addition were investigated under different $\mathrm{pH}$ conditions for the fermentation of waste activated sludge. Better performance was achieved in steel slag addition scenarios for both sludge hydrolysis and acidification. More solubilization of organic matters and much production of higher VFA (volatile fatty acid) in a shorter time can be achieved at $\mathrm{pH}$. 10 when adjusted by steel slag. Higher enzyme activities were also observed in steel slag addition scenarios under the same $\mathrm{pH}$ conditions. Phosphorus concentration in the supernatant increased with fermentation time and $\mathrm{pH}$ in $\mathrm{NaOH}$ addition scenarios, while in contrast most phosphorus was released and captured by steel slag simultaneously in steel slag addition scenarios. These results suggest that steel slag can be used as a substitute for $\mathrm{NaOH}$ in sludge alkaline treatment.
\end{abstract}

\section{Keywords}

addition, sludge, sodium, hydrolysis, hydroxide, steel, slag, acidification, activated, comparison, waste, between

\section{Disciplines}

Engineering | Science and Technology Studies

\section{Publication Details}

Zhang, Y., Zhang, C., Zhang, X., Feng, L., Li, Y. \& Zhou, Q. (2016). Waste activated sludge hydrolysis and acidification: a comparison between sodium hydroxide and steel slag addition. Journal of Environmental Sciences (China), 48 200-208.

\section{Authors}

Ying Zhang, Chaojie Zhang, Xuan Zhang, Leiyu Feng, Yongmei Li, and Qi Zhou 


\title{
Waste activated sludge hydrolysis and acidification: A comparison between sodium hydroxide and steel slag addition
}

\author{
Ying Zhang ${ }^{1,2}$, Chaojie Zhang ${ }^{1,{ }^{*}}$, Leiyu Feng ${ }^{1}$, Qi Zhou ${ }^{1}$ \\ ${ }^{1}$ State Key Laboratory of Pollution Control and Resources Reuse, School of Environmental \\ Science and Engineering, Tongji University, 1239 Siping Road, Shanghai 200092, China \\ ${ }^{2}$ School of Civil, Mining and Environmental Engineering, Faculty of Engineering and \\ Information Sciences, University of Wollongong, NSW 2522, Australia
}

\begin{abstract}
Alkaline treatment with steel slag and $\mathrm{NaOH}$ addition were investigated at different $\mathrm{pH}$ conditions for the fermentation of waste activated sludge. Better performance was achieved in steel slag addition scenarios for both sludge hydrolysis and acidification. More solubilization of organic matters and much higher (volatile fatty acids) VFAs production at a shorter time can be achieved at $\mathrm{pH} 10$ adjusted by steel slag. Higher enzyme activities were also observed in steel slag addition scenarios under same $\mathrm{pH}$ conditions. Phosphorus concentration in supernatant increased with fermentation time and $\mathrm{pH}$ in $\mathrm{NaOH}$ addition scenarios while in contrast most phosphorus were released and captured by steel slag simultaneously in steel slag addition scenarios. These results suggest that steel slag can be used as a substitute for $\mathrm{NaOH}$ in sludge alkaline treatment.
\end{abstract}

\section{Key Words}

Waste activated sludge; alkaline treatment; sodium hydroxide; steel slag

\footnotetext{
* Corresponding author

E-mail address: myrazh@tongji.edu.cn, Tel: 86-21-65983869,Fax:86-21-3869
} 


\section{Introduction}

The number of wastewater treatment plants (WWTPs) worldwide has increased dramatically in recent decades due to rapid urbanization and population growth, resulting in a significant increase of waste activated sludge (WAS) production. Typically, WAS contains a large amount of organics, heavy metals and pathogens, which post great threats to the environment, and its disposal cost can account for $20-60 \%$ of capital and operating cost of WWTP(Fang et al., 2014; Su et al., 2013).Therefore, environmental friendly and cost-effective means for sludge disposal are in great need. Anaerobic digestion is one of the most widely used methods for activated sludge stabilization. Worldwide attention has been drawn to this technique due to its capability of simultaneously achieving sludge mass reduction and generating valuable products including methane which is regarded as an important energy source and volatile fatty acids (VFAs) which could be used as carbon sources to enhance biological nutrient removal in WWTPs(Chen et al., 2007; Su et al., 2013). However, the applications of anaerobic digestion were often featured by long retention time (20-50 days), large digester volumes and low overall degradation efficiency (20-50\%)(Kim et al., 2010). Among the well-known three steps involved in anaerobic digestion, the hydrolysis step has been identified as the rate-limiting step(Higgins and Novak, 1997).And the major reasons for the less digestibility are the microbial cell walls containing glycan strands cross-linked by peptide chains and the existence of a large amount of extracellular polymeric substances (EPS)(Devlin et al., 2011).In order to improve the hydrolysis 
efficiency and digestibility of sludge, various pretreatment methods also referred as sludge disintegration techniques have been investigated, including chemical treatment using alkaline, acid or ozone(Devlin et al., 2011; Li et al., 2012; Zhang et al., 2009), mechanical treatment with ultrasound, high pressure homogenizer or ball milling(Apul and Sanin, 2010; Wett et al., 2010; Zhang et al., 2012), thermal treatment(Xue et al., 2015), additional enzymes treatment(Yang et al., 2010) and some of their combinations(Kim et al., 2010; Shehu et al., 2012). These pretreatment can normally destruct sludge flocs and cell walls, release intracellular and extracellular organic matters, and consequently accelerate sludge hydrolysis.

Alkaline treatment is a widely examined sludge disintegration method which is believed to be very effective in terms of solubilizing cellular substances and EPS (Fang et al., 2014; Li et al., 2008). Compared to other methods, alkaline treatment holds the advantages of simple devices, easy operation and lower energy demand. In addition, alkaline conditions are particularly favourable to the production of short-chain fatty acids (SCFAs)or VFAs which are suitable carbon sources for biological nutrient removal processes and phosphorus recovery with MAP (magnesium ammonium phosphate hexahydrate) or HAP(calcium phosphates)(Tong and Chen, 2007). $\mathrm{NaOH}$ was the most commonly used chemical for alkaline treatment and has been found to be more effective in terms of sludge disintegration than lime $\left(\mathrm{Ca}(\mathrm{OH})_{2}\right)(\mathrm{Li}$ et al., 2008). However, the consumption of $\mathrm{NaOH}$ involves a higher chemical cost and thus will increase sludge treatment expense. New alternative chemicals with low cost must be 
further explored.

Steel slag is a porous non-metallic by-product produced in steelmaking industry, the amount of which can be equivalent to $10-20 \%$ of crude steel output. Every year there would be around 100 million tons of steel slag generated in China, while only $50-60 \%$ of them can be resourcelized in proper ways, leaving a large amount of slag piled in the steel plant, which poses a great threat to the groundwater quality. Although the chemical composition of steel slag varies with different slag production processes, normally it consists of $\mathrm{CaO}, \mathrm{SiO}_{2}, \mathrm{FeO}, \mathrm{MgO}, \mathrm{Al}_{2} \mathrm{O}_{3}, \mathrm{MnO}, \mathrm{P}_{2} \mathrm{O}_{5}$, etc.(Shi, 2004) Steel slag has been used for treating acid mine drainage since its alkaline compounds such as lime and magnesia can leach out, creating high levels of alkalinity(Simmons et al., 2002). Meanwhile, steel slag was found to be a very effective material for phosphorus removal in wastewater as a result of phosphorus adsorption onto metal oxides/oxyhydroxides throughout the porous slag matrix and on slag surface, and precipitation in forms of metal-phosphates such as Fe-phosphates and Ca-phosphates(Pratt et al., 2007). In literature, however, the enhancement of sludge hydrolysis and acidification by steel slag has never been studied although the capability of creating alkalinity and phosphorus capture make it a potential chemical for sludge alkaline treatment.

Therefore, the purpose of this study was to investigate the feasibility of steel slag addition as a substitute of $\mathrm{NaOH}$ for sludge hydrolysis and acidification enhancement and phosphorus recovery. As $\mathrm{pH}$ is a key parameter in the case of alkaline or acid treatment, the effect of steel slag addition for different $\mathrm{pHs}$ conditions on WAS 
hydrolysis and acidification was studied in comparison with $\mathrm{NaOH}$ addition scenarios.

\section{Materials and Methods}

\subsection{Sludge and Steel Slag}

The waste activated sludge used in this study was collected from the secondary sedimentation tank of a municipal wastewater treatment plant in Shanghai, China. The plant is operated with an EBPR (enhanced biological phosphorus removal) process. The sludge was concentrated by settling at $4{ }^{\circ} \mathrm{C}$ for $12 \mathrm{~h}$ and was measured after that (Table 1).

The steel slag used in this work was obtained from Baoshan Iron \& Steel Co. Ltd in Shanghai, China. The Steel Slag was crushed and sifted through a 50-meshsieve before being added into the WAS. Elemental composition analysis with EDS (Energy Dispersive Spectroscopy) showed the elemental composition (expressed as atomic percentage) of the steel slag to be O 33.7\%, Fe 22.4\%, C 15.6\%, Ca 10.9\%, Mg 6.5\%, Mn 3.2\%, Au 2.4\%, Si 2.3\%, etc.

\subsection{Experimental Procedure}

Nine 1L glass vessels with working volume of $0.9 \mathrm{~L}$ were utilized as the anaerobic fermentation reactors. $0.9 \mathrm{~L}$ of WAS were fed into each reactor. The $\mathrm{pH}$ in reactor 1-4 was controlled at 8.0, 9.0, 10.0 and 11.0 with steel slag and the same $\mathrm{pH}$ in reactor 5-8 with sodium hydroxide. The reactor 9 , in which the $\mathrm{pH}$ was not adjusted, was set as the blank test. After 5 min nitrogen blowing, all reactors were placed in a shaking incubator maintained at the temperature of $25 \pm 1^{\circ} \mathrm{C}$ with a shaking speed of 100 revolutions per 
minute (rpm). Samples of the mixed liquor were taken at intervals. Supernatant samples were obtained after 3 min settling of the mixed liquor.

\subsection{Analytical Method}

Water content, TS (total solids), VS (volatile solids), and COD (chemical oxygen demand) were determined according to the standard methods (APHA et al., 2012).Sludge $\mathrm{pH}$ was measured with a $\mathrm{pH}$ meter (EUTECH Cyberscan510, Singapore). $\mathrm{PO}_{4}{ }^{3-}-\mathrm{P}$ and total phosphorus (TP) of the supernatant were also analyzed according to the standard methods(APHA et al., 2012).TP in steel slag was determined by Capacity Method of Ammonium Phosphomolybdate (Song, 2007), while TP in the sludge was measured by Vanadium Molybdate Yellow Colorimetric Method after Microwave Digestion (Wen et al., 2003). Soluble carbohydrates were determined using phenol-sulfuric acid method(Miller, 1959). Soluble protein was determined by the Lowry-Folin method with BSA (Bovin Serum Albumin) as standard (Lowry et al., 1951).

Total organic Carbon (TOC) was determined using a TOC-VCPN Analyzer (Shimadzu, Tokyo).An Agilent $6890 \mathrm{~N} \mathrm{GC}$ with flame ionization detector equipped with a $30 \mathrm{~m} \times$ $0.32 \mathrm{~mm} \times 0.25 \mu \mathrm{m}$ CPWAX52CB column was utilized to analyze the composition of VFAs. Analytical Method used in the analysis was developed according to (Chen et al., 2007). The microstructures and elemental composition of the steel slag were examined by scanning electron microscopy equipped with energy dispersive X-ray spectroscopy 
(SEM-EDX, Hitachi Co., S-4800,Japan)

Enzyme activities of four hydrolytic enzymes including protease, $\alpha$-glucosidase, alkaline and acid phosphatase were measured as per (Nybroe et al., 1992). Activities of five enzymes involved in acid fermentation were examined. The measurement of acetate kinase (AK) activity and butyrate kinase (BK) activity were carried out as per (Allen et al., 1964); while phosphate transacetylase (PTA) and phosphate transbutyrylase (PTB) were carried out as per (Andersch et al., 1983); oxaloacetate transcarboxylase (OAATC) activity was carried out as per (Wood et al., 1969).

\section{Results and Discussion}

\subsection{Sludge disintegration}

Alkaline disintegration of WAS accelerates hydrolysis by disruption of flocs and sludge cells which leads to the release and solubilization of extracellular and intracellular organic matters (Doğan and Sanin, 2009; Fang et al., 2014; Li et al., 2008). Thus, the effect of steel slag and $\mathrm{NaOH}$ addition on sludge integration can be expressed by the change of STOC (soluble total organic carbon) which is determined by measuring TOC of supernatant. Figure1 shows the effect of steel slag and $\mathrm{NaOH}$ addition on STOC during WAS fermentation within 20 days at different $\mathrm{pHs}$. It was found that the concentration of STOC under both $\mathrm{NaOH}$ and steel slag adjusted conditions (Abbreviations were used in following. $\mathrm{NAC}$, for $\mathrm{NaOH}$ adjusted conditions; SSAC for steel slag adjusted conditions) increased gradually with the fermentation time. In the selected range of $\mathrm{pH}$, more solubilization of organics was observed at higher $\mathrm{pH}$, 
coincident with previous studies (Chen et al., 2007; Doğan and Sanin, 2009) in which SCOD was used as an indicator. It is worth noting that at higher $\mathrm{pHs}(\mathrm{pH} 10$ and11) SSAC had a significant higher value of STOC than that of NAC after 10d fermentation. The STOC was 393 and $963 \mathrm{mg} / \mathrm{L}$ higher in fermentation reactors with SSAC at fermentation time $20 \mathrm{~d}$ for $\mathrm{pH} 10$ and $\mathrm{pH} 11$, respectively, indicating that steel slag may be better than $\mathrm{NaOH}$ in the enhancement of sludge disintegration.

\subsection{Protein and carbonhydrate solubilization}

It has been reported that protein and carbohydrate are the predominant constituents of extracellular polymetric substances (EPS) in WAS (Chen et al., 2007; Yan et al., 2010).In addition, alkaline treatment is believed to be very effective in solubilizing EPS (Chen et al., 2007; Fang et al., 2014). Thus, the solubilization of organic matters was expressed in terms of soluble protein and carbohydrate. As shown in Fig.2, the concentration of soluble protein and carbohydrate for both NAC and SSAC reactors increased with $\mathrm{pH}$, which is in accordance with the change of STOC. Besides, the concentration at alkaline $\mathrm{pH}(\mathrm{pH}=9,10,11)$ was much higher than that at near neutral $\mathrm{pH}($ blank and $\mathrm{pH}=8)$. This is probably because the alkaline $\mathrm{pH}$ resulted in the dissociation of acidic groups in EPS and repulsions between the negatively charged EPS (Wingender et al., 1999). In agreement with literature (Chen et al., 2007; Su et al., 2013), the concentrations of soluble protein and carbohydrate fluctuated slightly with the increase of fermentation time in both NAC and SSAC reactors due to the competition between solubilization and degradation. Especially for carbohydrate, its concentration 
showed an obvious decline after $10 \mathrm{~d}$, whereas the soluble protein concentration tended to remain constant after $12 \mathrm{~d}$. The rate of carbohydrate concentration decline was lower at $\mathrm{pH} 11$ than other scenarios in both NAC and SSAC reactors, which indicated that the degradation rate of carbohydrate might be reduced under strongly basic condition. The carbohydrate concentration in SSAC was slightly higher than that of NAC. However, a remarkable difference was observed between the protein concentration of SSAC and $\mathrm{NAC}$ with the highest concentration $2300 \mathrm{mg} / \mathrm{L}$ and $1500 \mathrm{mg} / \mathrm{L}$, respectively, further demonstrating that steel slag has an advantage over $\mathrm{NaOH}$ in terms of sludge solubilization, which might result from the concomitant mechanical disruption of microbial cells due to the existence of insoluble steel slag particulates.

\subsection{VFAs production and composition}

Total VFAs production from WAS was defined as the sum of the concentrations of acetic, propionic, n-butyric, isobutyric, n-valeric and isovaleric acids( $\mathrm{Su}$ et al., 2013). The total VFAs production at different $\mathrm{pHs}$ adjusted by $\mathrm{NaOH}$ and steel slag is shown in Fig.3A and Fig.3B. In both NAC and SSAC fermentation reactors, VFAs concentration increased with fermentation time gradually, and then decreased after reaching the highest around $6 \sim 9 \mathrm{~d}$ at all $\mathrm{pHs}$ except for $\mathrm{pH} 11$. At $\mathrm{pH} 11$,VFAs concentration kept rising during fermentation time of $20 \mathrm{~d}$, which was in accordance with (Chen et al., 2007), where the initial less VFAs production was explained as ineffectiveness of acidogenic bacteria due to toxic effects of the strongly basic condition and the subsequent significant increase showed the adaptation of bacteria to the 
environment. The greatest VFAs production was observed at $\mathrm{pH} 10$, which was $3431 \mathrm{mg} / \mathrm{L}$ and $3981 \mathrm{mg} / \mathrm{L}$ for NAC and SSAC reactors, respectively. Not only did SSAC have a higher VFAs production, but also it took a shorter time (6d versus $8 \mathrm{~d}$ ) to reach the highest. As is well known, three stages are included in sludge anaerobic fermentation: hydrolysis, acidification and methane generation. The better performance of steel slag addition in VFAs production could be caused by either more soluble substrate for acidification due to higher hydrolysis rate or inhibition of methanogens activities (Yuan et al., 2006). It has been demonstrated that more soluble protein and carbohydrate were available in SSAC fermentation reactors, while methanogens activities has not been examined in this study, which should be further investigated in future work.

Figure 3C and Figure 3D shows the percentage of individual VFAs accounting for total VFAs at different pHs when total VFAs was at the highest level. All six common short-chain fatty acids in WAS (acetic, propionic, n-butyric, isobutyric, n-valeric and isovaleric acids) were detected. In agreement with literature(Chen et al., 2007; Su et al., 2013), acetic acid was the prevalent acid and its proportion tended to be greater at higher $\mathrm{pH}$, probably owing to the inhibition effect of stronger alkaline conditions on methanogens and the subsequent less consumption of acetic acid. The order of individual VFAs wasacetic $>$ propionic $>$ (isovaleric, isobutyric) $>(n$-butyric, n-valeric). No obvious difference was discovered between NAC and SSAC in terms of VFAs composition. 


\section{$3.4 \mathrm{PO}_{4}{ }^{3-}$ release}

Figure 4 shows the variation of orthophosphate concentration at different $\mathrm{pHs}$ in NAC and SSAC fermentation reactors. In NAC reactor, it can be seen that orthophosphate concentration increased gradually with fermentation time as well as pHs. Highest concentration observed at $\mathrm{pH} 11$ with $20 \mathrm{~d}$ was $250 \mathrm{mg} / \mathrm{L}$, which could be explained that stronger alkaline conditions were more effective in cell lysis and more nucleic acids were released and hydrolyzed. In addition, further disruption of sludge cells at $\mathrm{pH} 11$ and above 11 may lead to disruption of cell membranes composed of phospholipids bilayer and thus more phosphorus will be released(Bi et al., 2014). However, in SSAC reactors, almost no orthophosphate was detected after $1 \mathrm{~d}$ fermentation. Two possible reasons for this phenomenon are: the addition of steel slag significantly inhibited sludge phosphorus release; or the orthophosphate released into supernatant was captured by steel slag particles. In order to further explore the reason, the distribution of total phosphorus was examined (Fig.5). The proportion of TP in sludge declined along with fermentation time in both NAC and SSAC reactors, while the majority of TP migrated into steel slag rather than supernatant in SSAC. Also, SEM-EDX analysis was conducted to investigate morphology and elemental composition of steel slag before and after the fermentation. Although no obvious morphology difference was found between the SEM images, an apparent phosphorus percentage change in the elemental composition of steel slag surface was observed (Table 2), further demonstrating that a large amount of phosphorus was transferred to the surface of steel slag, which could be 
caused by either adsorption or precipitation as mentioned above in introduction. After fermentation of 20 days at $\mathrm{pH} 11,91.6 \% \mathrm{TP}$ was released and mitigated to steel slag, whereas $85.0 \%$ TP was observed in the supernatant of NAC. Therefore, by steel slag addition the release of phosphorus in sludge was enhanced and simultaneously removed effectively from supernatant.

\subsection{Enzyme activities}

Major constituents of WAS such as protein and carbohydrate are all biological macromolecules. Their degradation are heavily dependent on microorganisms and enzymes. Thus, the activities of key enzymes for hydrolysis and VFAs production were examined to further understand the effect of $\mathrm{NaOH}$ and steel slag addition on WAS fermentation. Four hydrolytic enzymes (protease, $\alpha$-glucosidase, alkaline phosphatase and acid phosphatase) and five acid-forming enzymes (AK, BK, PTA, PTB and OAATC) were selected for this study. Usually, the protease breaks the peptide bonds in protein molecules, while $\alpha$-glucosidase breaks the linkage in maltose to release glucose. Phosphatase hydrolyzes phosphate esters and releases the phosphate group, and acid/alkaline phosphatase differs in $\mathrm{pH}$ optimum for maximum activity as well as the reaction mechanisms on different substrates(Goel et al., 1998). Figure 6A 6D shows the variation of hydrolytic enzyme activities at different $\mathrm{pHs}$ in NAC and SSAC. It was obvious that alkaline treatment had a positive effect on hydrolytic enzyme activities, probably because of more substrate available under alkaline conditions. The highest 
enzyme activities of protease, $\alpha$-glucosidase, alkaline phosphatase and acid phosphatase observed were in the fifth day of $\mathrm{pH} 10$ with the value of 4.93,110.6, 83.0, $16.2 \mathrm{U} / \mathrm{g}$ VSS for NAC, and 5.88, 119.8, 90.5, 17.6 U/g VSS for SSAC. Although pH 10 may not be the optimal $\mathrm{pH}$ for these enzymes, this result indicates that in this process the enhancement of enzyme activity by extra amount of substrates can outweigh the negative effect of non-optimal $\mathrm{pH}$. Hydrolytic enzymes in SSAC showed higher activities than that of NAC, which may result from its better performance in sludge solubilization and could contribute to more phosphorus release and VFAs production. It is noted that at $\mathrm{pH} 11$ longer time was required to reach the highest enzyme activities than any other $\mathrm{pHs}$ and the activities were lower than that of $\mathrm{pH} 10$ even with a higher organic matter solubilization at $\mathrm{pH} 11$, which suggested that $\mathrm{pH}$ higher than 10 had a stronger inhibitory effect on enzyme activities, in accordance with the less effectiveness of $\mathrm{pH} 11$ at VFAs production at the initial days of fermentation. In all scenarios, the enzyme activities decreased gradually after reaching the highest values possibly because the accumulation of products inhibited the enzymatic reaction. In the literature, Feng et al. (2009) proposed a metabolic pathway for VFAs production from protein and carbohydrate in which AK, BK, PTA, PTB and OAATC were identified as the key enzymes to transform the hydrolytic products of protein and carbohydrate into VFAs. Fig.6E 6I shows the variation of acid-forming enzyme activities at different $\mathrm{pHs}$ in NAC and SSAC. The highest activities of AK, BK, PTA, PTB and OAATC were observed at $\mathrm{pH} 10,6 \mathrm{~d}$ and $8 \mathrm{~d}$ for NAC and SSAC, respectively, 
which was in good agreement with the highest total VFAs production mentioned above. And the activities of key enzymes in SSAC were slightly higher $(5.88,4.30,0.21$, $0.0032,1.41 \mathrm{U} / \mathrm{g}$ VSS $)$ than those in NAC $(4.93,4.19,0.18,0.0030,1.30 \mathrm{U} / \mathrm{g}$ VSS $)$.

\section{Conclusions}

Alkaline treatment with steel slag addition showed a better performance than $\mathrm{NaOH}$ in the solubilization of organic matters and VFAs production. Higher enzyme activities were also observed in SSAC than NAC under same $\mathrm{pH}$ condition. Orthophosphate concentration in supernatant increased with fermentation time and $\mathrm{pH}$ in $\mathrm{NAC}$ while in contrast most orthophosphate released in SSAC were mitigated to steel slag. These results demonstrated that steel slag can be used as a substitute for $\mathrm{NaOH}$ in sludge alkaline treatment. Moreover, the steel slags which successful captured a large amount of phosphorus could be further used as efficient agriculture fertilizers.

\section{Acknowledgements}

This study was financially supported by the National Hi-Tech Research and

Development Program of China (863) (20110609).

\section{References}

Allen, S H G, Kellermeyer, R W, Stjernholm, R L, Wood, H G, 1964. Purification and properties of enzymes involved in the propionic acid fermentation. Journal of bacteriology 87:171-187.

Andersch, W, Bahl, H, Gottschalk, G, 1983. Level of enzymes involved in acetate, butyrate, acetone and butanol formation by Clostridium acetobutylicum. European journal of applied microbiology and biotechnology 18:327-332.

APHA, AWWA, WEF, 2012. Standard Methods for the Examination of Water and Wastewater, 22nd ed. American Public Health Association, Washington,D.C.,USA. 
Apul, O G, Sanin, F D, 2010. Ultrasonic pretreatment and subsequent anaerobic digestion under different operational conditions. Bioresource technology 101:8984-8992.

Bi, W, Li, Y, Hu, Y, 2014. Recovery of phosphorus and nitrogen from alkaline hydrolysis supernatant of excess sludge by magnesium ammonium phosphate. Bioresource Technology 166:1-8.

Chen, Y, Jiang, S, Yuan, H, Zhou, Q, Gu, G, 2007. Hydrolysis and acidification of waste activated sludge at different pHs. Water Research 41:683-689.

Devlin, D C, Esteves, S R R, Dinsdale, R M, Guwy, A J, 2011. The effect of acid pretreatment on the anaerobic digestion and dewatering of waste activated sludge. Bioresource Technology 102:4076-4082.

Doğan, I, Sanin, F D, 2009. Alkaline solubilization and microwave irradiation as a combined sludge disintegration and minimization method. Water Research 43:2139-2148.

Fang, W, Zhang, P, Zhang, G, Jin, S, Li, D, Zhang, M, Xu, X, 2014. Effect of alkaline addition on anaerobic sludge digestion with combined pretreatment of alkaline and high pressure homogenization. Bioresource Technology 168:167-172.

Goel, R, Mino, T, Satoh, H, Matsuo, T, 1998. Enzyme activities under anaerobic and aerobic conditions in activated sludge sequencing batch reactor. Water Research 32:2081-2088.

Higgins, M, Novak, J, 1997. Characterization of Exocellular Protein and Its Role in Bioflocculation. Journal of Environmental Engineering 123:479-485.

Kim, D-H, Jeong, E, Oh, S-E, Shin, H-S, 2010. Combined (alkaline+ultrasonic) pretreatment effect on sewage sludge disintegration. Water Research 44:3093-3100. Li, H, Jin, Y, Mahar, R, Wang, Z, Nie, Y, 2008. Effects and model of alkaline waste activated sludge treatment. Bioresource Technology 99:5140-5144.

Li, H, Li, C, Liu, W, Zou, S, 2012. Optimized alkaline pretreatment of sludge before anaerobic digestion. Bioresource Technology 123:189-194.

Lowry, O H, Rosebrough, N J, Farr, A L, Randall, R J, 1951. Protein measurement with the Folin phenol reagent. J biol Chem 193:265-275.

Miller, G L, 1959. Use of Dinitrosalicylic Acid Reagent for Determination of Reducing Sugar. Analytical Chemistry 31:426-428.

Nybroe, O, Jørgensen, P E, Henze, M, 1992. Enzyme activities in waste water and activated sludge. Water Research 26:579-584. 
Pratt, C, Shilton, A, Pratt, S, Haverkamp, R G, Bolan, N S, 2007. Phosphorus Removal Mechanisms in Active Slag Filters Treating Waste Stabilization Pond Effluent. Environmental Science \& Technology 41:3296-3301.

Shehu, M S, Abdul Manan, Z, Wan Alwi, S R, 2012. Optimization of thermo-alkaline disintegration of sewage sludge for enhanced biogas yield. Bioresource Technology 114:69-74.

Shi, C, 2004. Steel Slag-Its Production, Processing, Characteristics, and Cementitious Properties. Journal of Materials in Civil Engineering 16:230-236.

Simmons, J, Ziemkiewicz, P, Black, D C, 2002. Use of steel slag leach beds for the treatment of acid mine drainage. Mine Water and the Environment 21:91-99.

Song, W, 2007. Discussion on determining phosphor in steel by capacity method of ammonium phosphomolybdate (In Chinese with an English Abstract). Metallurgical collections 168:16-18.

Su, G, Huo, M, Yuan, Z, Wang, S, Peng, Y, 2013. Hydrolysis, acidification and dewaterability of waste activated sludge under alkaline conditions: Combined effects of $\mathrm{NaOH}$ and $\mathrm{Ca}(\mathrm{OH}) 2$. Bioresource Technology 136:237-243.

Tong, J, Chen, Y, 2007. Enhanced Biological Phosphorus Removal Driven by Short-Chain Fatty Acids Produced from Waste Activated Sludge Alkaline Fermentation. Environmental Science \& Technology 41:7126-7130.

Wen, X, Huang, L, Li, D, 2003. Determination of Phosphorus in Sludge by Microwave Digestion Spectrophotometric. Nonferrous Metals Engineering \& Research 24:88-90. Wett, B, Phothilangka, P, Eladawy, A, 2010. Systematic comparison of mechanical and thermal sludge disintegration technologies. Waste management 30:1057-1062. Wingender, J, Neu, T R, Flemming, H-C, 1999. Microbial extracellular polymeric substances: characterization, structure, and function. Springer.

Wood, H G, Jacobson, B, Gerwin, B I, Northrop, D B, 1969. Oxaloacetate transcarboxylase from Propionibacterium. Methods in Enzymology 13:215-230.

Xue, Y, Liu, H, Chen, S, Dichtl, N, Dai, X, Li, N, 2015. Effects of thermal hydrolysis on organic matter solubilization and anaerobic digestion of high solid sludge. Chemical Engineering Journal 264:174-180.

Yan, Y, Feng, L, Zhang, C, Wisniewski, C, Zhou, Q, 2010. Ultrasonic enhancement of waste activated sludge hydrolysis and volatile fatty acids accumulation at $\mathrm{pH} 10.0$. Water Research 44:3329-3336.

Yang, Q, Luo, K, Li, X-m, Wang, D-b, Zheng, W, Zeng, G-m, Liu, J-j, 2010. Enhanced 
efficiency of biological excess sludge hydrolysis under anaerobic digestion by additional enzymes. Bioresource Technology 101:2924-2930.

Yuan, H, Chen, Y, Zhang, H, Jiang, S, Zhou, Q, Gu, G, 2006. Improved Bioproduction of Short-Chain Fatty Acids (SCFAs) from Excess Sludge under Alkaline Conditions.

Environmental Science \& Technology 40:2025-2029.

Zhang, G, Yang, J, Liu, H, Zhang, J, 2009. Sludge ozonation: Disintegration, supernatant changes and mechanisms. Bioresource Technology 100:1505-1509.

Zhang, S, Zhang, P, Zhang, G, Fan, J, Zhang, Y, 2012. Enhancement of anaerobic sludge digestion by high-pressure homogenization. Bioresource technology 118:496-501.

\section{List of Tables}

Table 1 Characteristics of sludge

\begin{tabular}{ll}
\hline Parameter & Value \\
\hline $\mathrm{pH}$ & $6.8 \sim 7.0$ \\
Water Content (\%) & $97 \sim 98$ \\
Total Solids (TS, g/L) & $13 \sim 21$ \\
Volatile Solids (VS, g/L) & $6 \sim 14$ \\
Total Chemical Oxygen Demand (TCOD, $\mathrm{mg} / \mathrm{L})$ & $14000 \sim 20000$ \\
Soluble Chemical Oxygen Demand (SCOD, $\mathrm{mg} / \mathrm{L})$ & $40 \sim 100$ \\
\hline
\end{tabular}


Table 2 Elemental composition of steel slag before and after fermentation

\begin{tabular}{|c|c|c|c|c|}
\hline \multirow{3}{*}{ Elements } & \multicolumn{2}{|c|}{ Before fermentation } & \multicolumn{2}{|c|}{ After fermentation } \\
\hline & Weight & Atomic & Weight & Atomic \\
\hline & percentage $(\%)$ & percentage $(\%)$ & percentage $(\%)$ & percentage $(\%)$ \\
\hline $\mathrm{C}$ & 5.6 & 15.6 & 5.8 & 13.7 \\
\hline $\mathrm{O}$ & 16.1 & 33.7 & 17.1 & 34.9 \\
\hline $\mathrm{Na}$ & 0.6 & 0.9 & 0.3 & 0.6 \\
\hline $\mathrm{Mg}$ & 4.7 & 6.5 & 4.1 & 6.7 \\
\hline $\mathrm{Al}$ & 0.6 & 0.7 & 0.1 & 0.2 \\
\hline $\mathrm{Ca}$ & 13.2 & 10.9 & 13.1 & 12.4 \\
\hline $\mathrm{Fe}$ & 38.3 & 22.4 & 34.9 & 19.23 \\
\hline $\mathrm{P}$ & 0.8 & 0.85 & 8.9 & 7.4 \\
\hline $\mathrm{Si}$ & 1.9 & 2.3 & 0.7 & 1.1 \\
\hline $\mathrm{Cr}$ & 0.4 & 0.3 & 0.2 & 0.1 \\
\hline
\end{tabular}




\section{List of Figures}

A

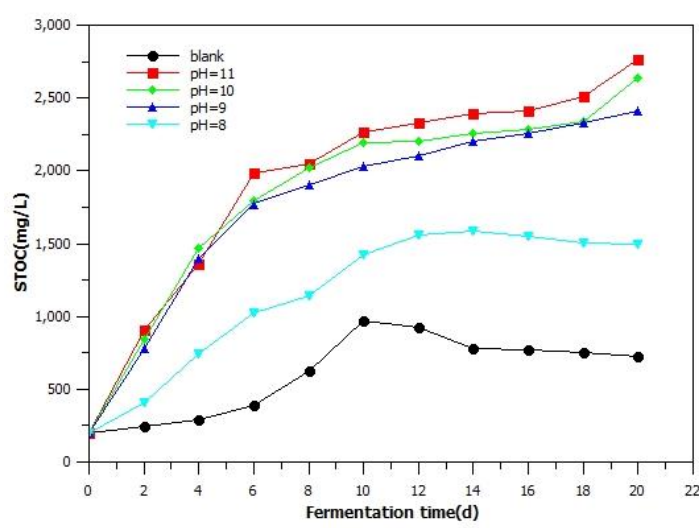

B

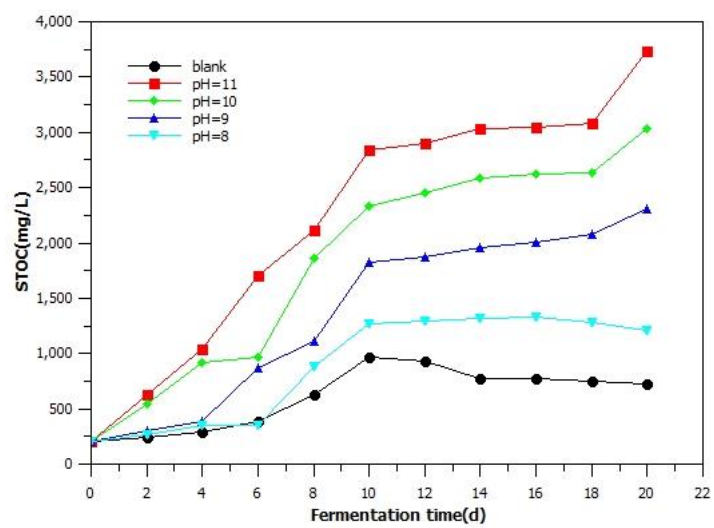

Fig.1 Variations of Organic matters solubilization at different pHs adjusted by $\mathrm{NaOH}$ (A) and steel slag (B) 


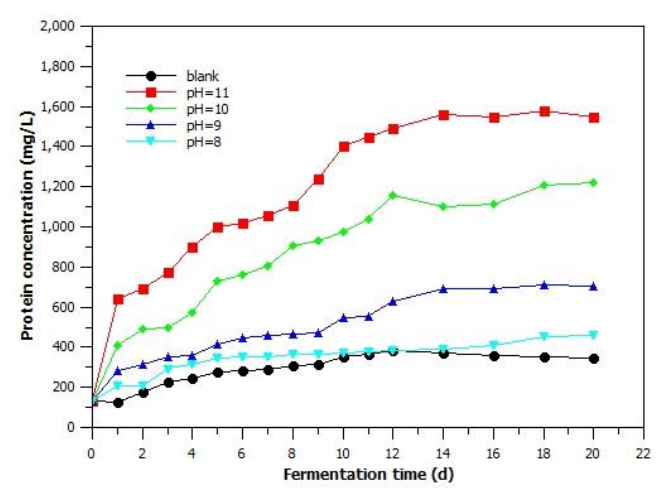

$\mathrm{C}$

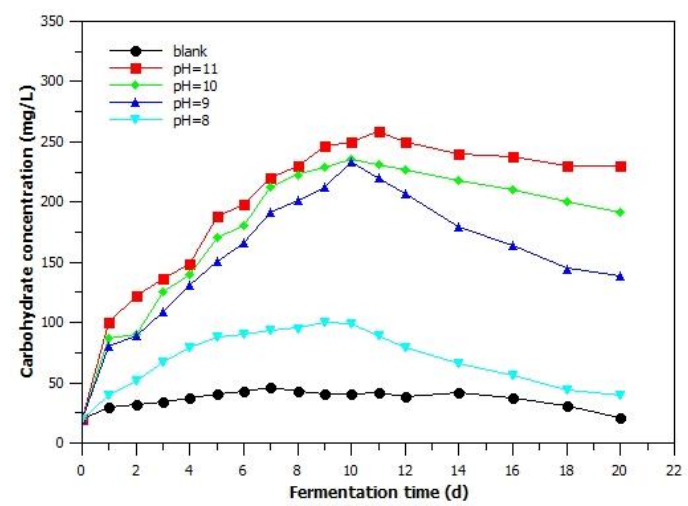

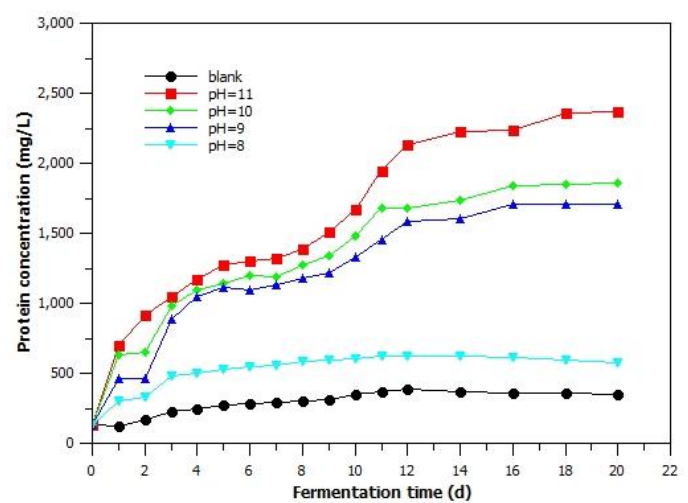

D

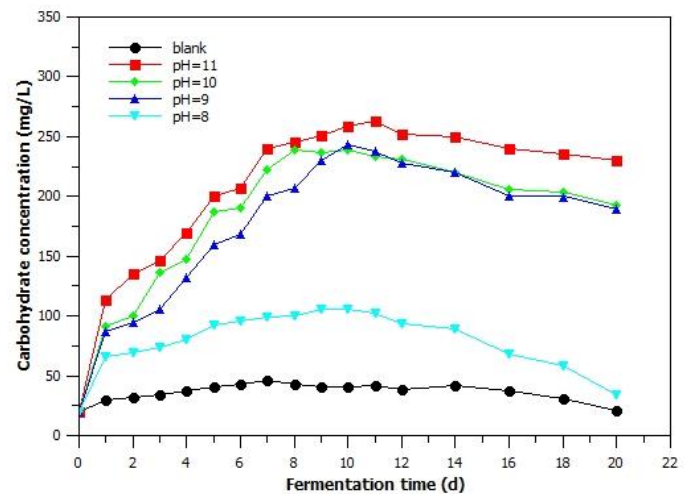

Fig.2 Variations of protein and carbohydrate concentration in supernatant at different 
pHs adjusted by $\mathrm{NaOH}$ and steel slag (A and $\mathrm{B}$ refer to the variation of protein concentration for NAC and SAC; C and D refer to the variation of carbohydrate concentration for NAC and SSAC, respectively.)
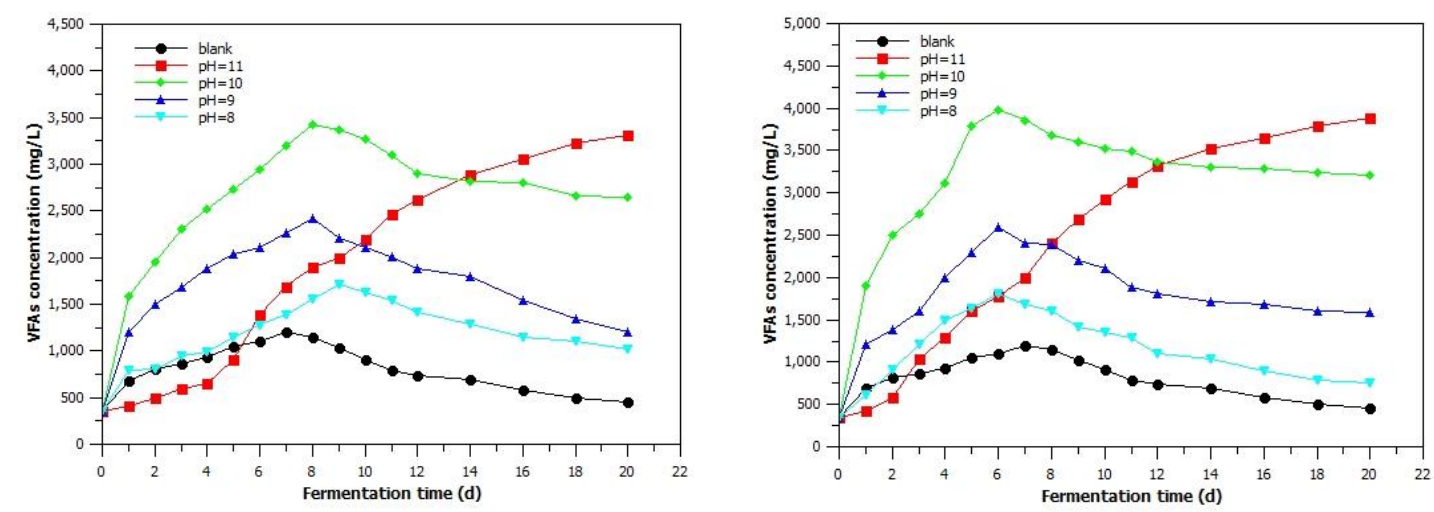

$\mathrm{C}$

$\mathrm{D}$
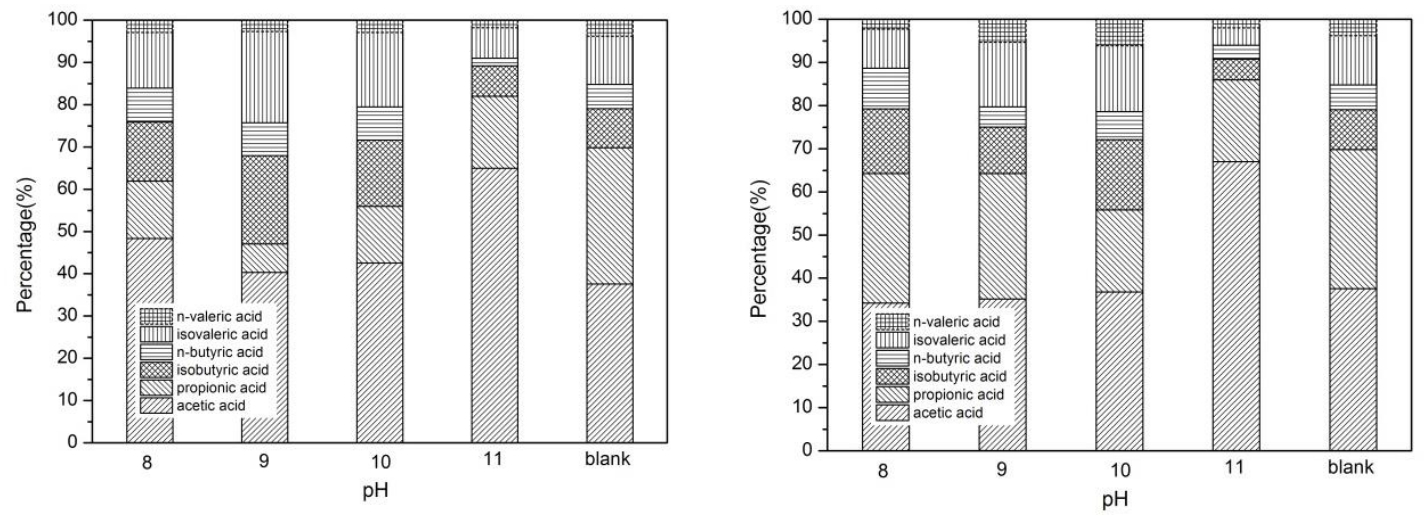

Fig.3 Variations of total VFAs concentration and VFAs composition in supernatant at 
different pHs adjusted by $\mathrm{NaOH}$ and steel slag ( $\mathrm{A}$ and $\mathrm{B}$ show the variation of total VFAs concentration for NAC and SAC; C and D show VFAs composition at highest total VFAs level for NAC and SSAC, respectively.)
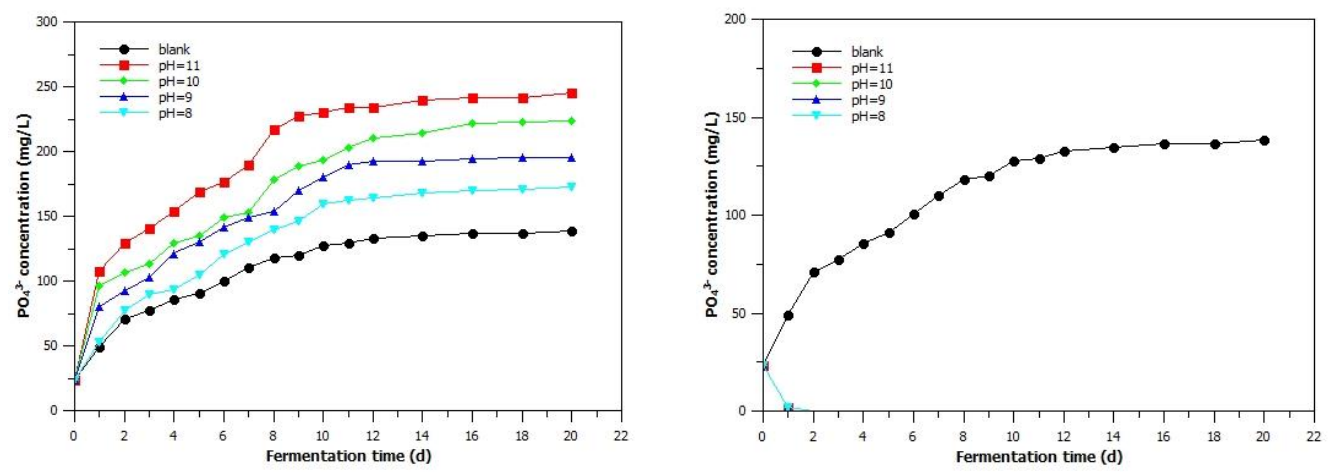

Fig.4 Variations of $\mathrm{PO}_{4}{ }^{3-}-\mathrm{P}$ concentration in supernatant at different pHs adjusted by $\mathrm{NaOH}$ (A)

and steel slag (B)
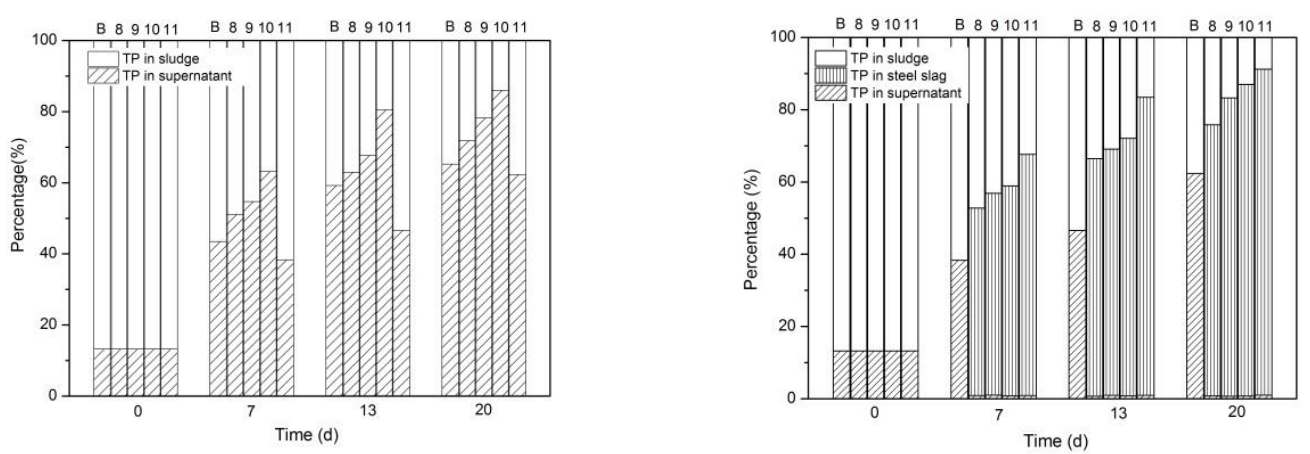
Fig.5 Variations of TP (total phosphorus) distribution at different pHs adjusted by $\mathrm{NaOH}$ (A) and steel slag (B) (In these columns, B refers to the blank test, and 8, 9, 10, 11 refer to the scenarios under these $\mathrm{pH}$ conditions)

A

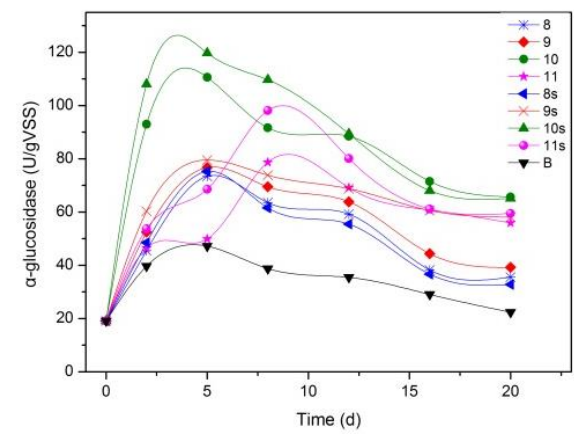

$\mathrm{C}$

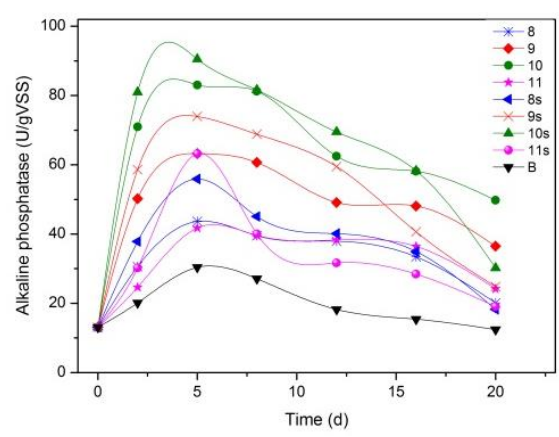

$\mathrm{E}$
B

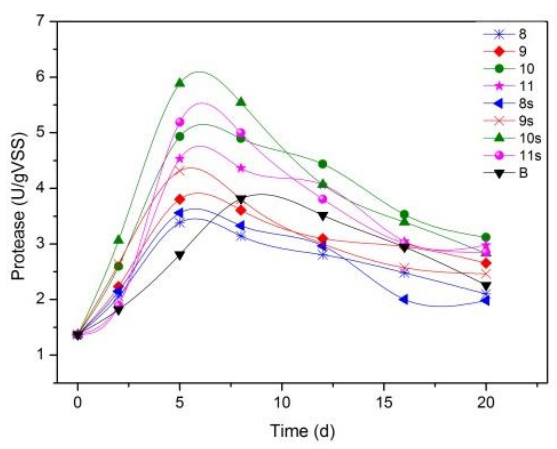

$\mathrm{D}$

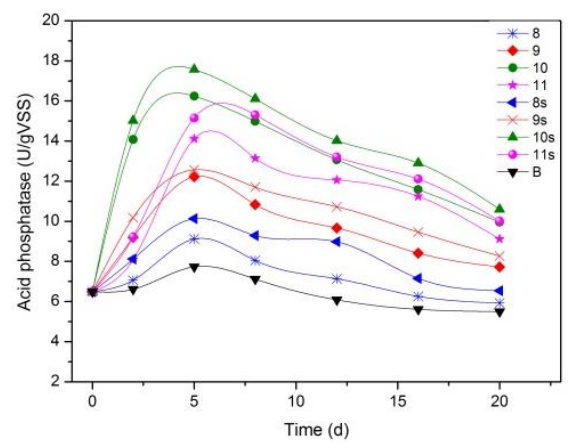

$\mathrm{F}$ 


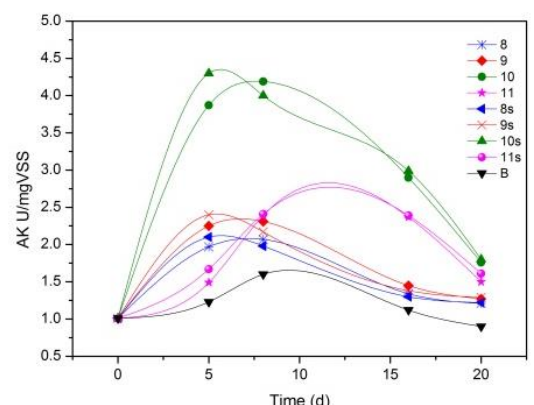

G

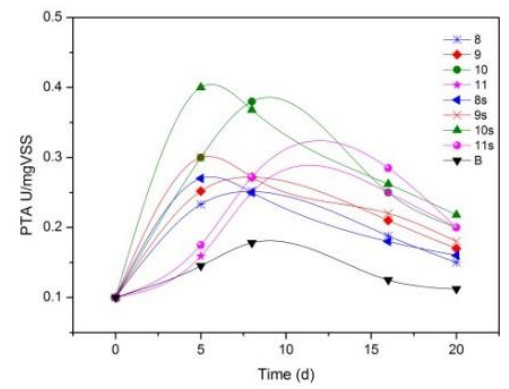

I

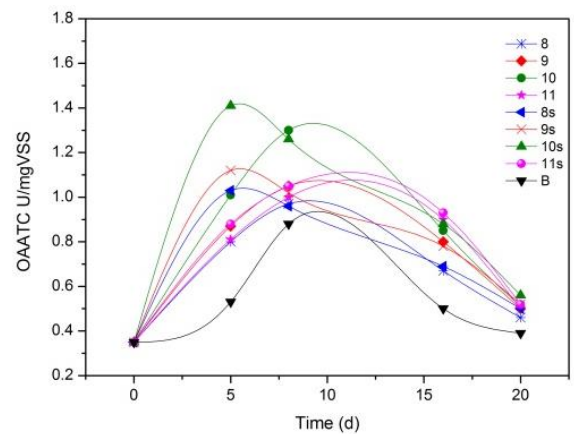

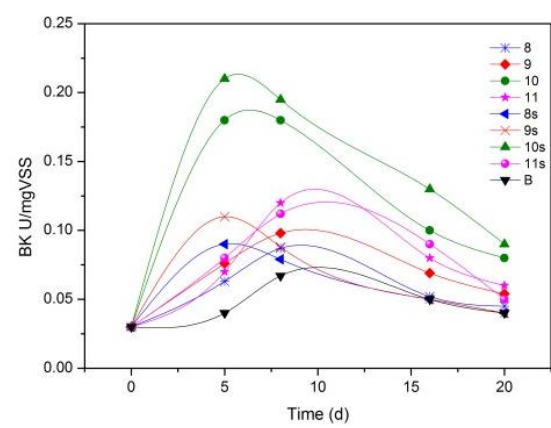

$\mathrm{H}$

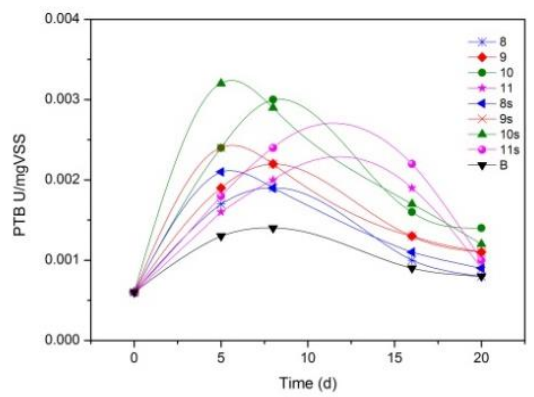

Fig.6 Variations of hydrolytic and acid-forming enzyme activities at different pHs (B refers to the blank test, and $8,9,10,11$ refer to the scenarios under these $\mathrm{pH}$ conditions adjusted by $\mathrm{NaOH}$, while $8 \mathrm{~s}, 9 \mathrm{~s}, 10 \mathrm{~s}, 11 \mathrm{~s}$ refer to the scenarios under these $\mathrm{pH}$ conditions adjusted by steel slag) 